\title{
Structural Power and Public Policy: A Signaling Model of Business Lobbying in Democratic Capitalism
}

\author{
Patrick Bernhagen \\ University of Aberdeen
}

\section{Thomas Bräuninger}

University of Konstanz

\begin{abstract}
This paper develops a signaling model of corporate lobbying in democratic capitalist societies to analyze the conditions that lead to a powerful political position of business. Proceeding from the traditional dichotomy of structural economic determinants versus business' political action, our model predicts the conditions under which elected political decisionmakers modify their policy pledges to accommodate business' political preferences, or override business' lobbying messages and honor their pledges. Our results show that the structural power of business over public policy is contingent on two variables: the size of reputation costs of business in relation to its material costs of lobbying; and the ratio of the policymaker's reputation constraints from policy commitments and campaign pledges to the electoral costs arising from adverse effects of policy. We evaluate our model using case studies of business lobbying on environmental and financial services regulation in Britain and Germany.
\end{abstract}

If politics is about who gets what, when and how, there is little doubt today that business is a successful political actor. ${ }^{1}$ To the extent that business wields a disproportionate influence over public policy, an increasing global integration of factor and goods markets further enhances the political power of business (Cerny, 1999). The normative implications are immense: if public policy is systematically biased in favor of business interests, political equality, democratic accountability, and the legitimacy of political outcomes are greatly undermined (Dahl, 1989, pp. 324-8). However, there is little consensus in the literature over what the sources of the political power of business are.

We can distinguish between accounts of the political involvement of business in democratic capitalism along the lines of intentional interference versus nonintentional domination. On the one side, studies of interest group politics and lobbying focus on the manifold pressures exerted on elected political decisionmakers (hereafter policymakers). They propose that business, like any other interest group, has to fight incessantly to avert unfavorable political outcomes (for example Vogel, 1996, p. 5-6). The other extreme is marked by the empirically elusive claim that the owners and managers of private enterprises enjoy a structurally powerful position that enables them to secure favorable political outcomes even if they abstain from political action. The prevalence of this paradigmatic divide has obscured an important aspect of public policymaking, that is the fact that policymakers face 
huge informational problems with regard to the economic consequences of policies as well as how these are valuated by citizens, while special interests has privileged access to the pertinent information (Potters and Van Winden, 1992).

In this paper, we remove some of this obscurity by looking at the ways in which business uses privately held information about the effects of policy in its political strategies. We modify existing models of strategic information transmission by special interest groups ${ }^{2}$ to take into account what distinguishes business from other societal interests: the prerogative of investment and allocation, and thereby of some of the most important decisions affecting both people's welfare and the fate of elected policymakers in democratic capitalist societies. We develop a formal model in which business communicates private information about the likelihood of adverse effects of a pending policy to the policymaker, who must infer the credibility of this signal from the observed levels of costly political action. The model predicts the conditions under which policymakers choose to override business complaints, and when they abandon or modify the policy.

Our approach is innovative in its focus on critical cases, in which elected politicians must consider calling off already-made policy pledges in order to cater to business interests. It has been argued that any assessment of the political power of business should focus on the agenda stage of the policy process (Crenson, 1971; Lukes, 1974). The rationale behind the study of 'non-decisionmaking' (Bachrach and Baratz, 1970) is that elected policymakers rarely make policy pledges in the first place that would conflict with powerful interests. Research on these covert sources of business influence over public policy, however, is plagued by fundamental methodological problems (Quinn and Shapiro, 1991, p. 868). Moreover, policymakers do commit to policies that are unpopular with business. Environmental policy measures or social-democratic redistributive policies are cases in point (Downs, 1972; Smith, 2000, p. 160). In light of these considerations, our approach can provide insights into the underlying mechanisms that determine the strength and scope of business structural power that are black-boxed by studies of agenda power. Furthermore, the study of critical cases is of substantive importance, as it provides a litmus test for what democratic elections are supposed to accomplish: having voters embrace a set of policies that elected officials will pursue.

In the following sections, we locate our approach in the context of existing theories of lobbying and business political power, using theory-informing data from interviews with lobbyists at German and Irish trade associations to calibrate our theoretical model. We then develop a formal signaling model of business lobbying and derive its equilibria. In subsequent sections we evaluate the model using two case studies of business lobbying on environmental policy and financial services regulation in Germany and Great Britain. We conclude by discussing possibilities for extensions and quantitative tests.

\section{Political Action, Structural Power, and Information: What's Special About Business?}

From the perspective of business politics as intentional influence, business aims to secure favorable political outcomes by lobbying. Lobbying refers to influencing the 
formation of public policy, its passage through the legislature and its implementation, by means of contacting and pressurizing policymakers such as individual legislators, ministers and civil servants (see Richardson, 1993, p. 1; Baumgartner and Leech, 1998, pp. 33-6). Research in this area concerns the resources available to business and its interest organizations (Getz, 1997), party and campaign finance (Wright, 1996) and outright corruption (Girling, 1997). It extends further into studying the means of business to influence public opinion (Mitchell, 1997, pp. 41-59; Smith, 2000, pp. 167-96) and the networks encompassing economic and political elites (Mills, 1956; Marsh and Rhodes, 1992). However, with respect to explaining legislative and regulatory outcomes by reference to overt political pressure from business, the empirical findings are mixed (Baumgartner and Leech, 1998, pp. 106-8; Smith, 2000, pp. 115-41). This lack of findings is not surprising, given that voters would generally be dissatisfied with policymakers selling out to big business (Morton and Cameron, 1992).

Yet at the aggregate level, political outcomes have been shown to be biased in favor of business interests. This bias is epitomized in the 'paradox of redistribution' that is characteristic of developed democracies: while in the political realm rights are distributed equally, the actual distributions of income and wealth are always such that the median falls short of the mean. Taking the median voter theorem seriously, the puzzle is why the poor, equipped with the right to vote, do not take away from the rich (Breyer and Ursprung, 1998). The persistence of a probusiness policy bias is then often explained by reference to non-intentional modes of political domination. Deriving from Marxist accounts of the role of the state, this line of reasoning concerns the structural constraints on the policymaking capacities of elected officials and has become known, variously, as the 'structural dependence of the state on capital' (Przeworski and Wallerstein, 1988; Swank, 1992), as the 'business confidence' factor (Block, 1977) or as the 'privileged position of business' (Lindblom, 1977, pp. 170-88). The argument asserts that the negative effects of redistribution on the share of profits consumed by capitalists lead to disincentives for investment, followed by the whole appendage of sluggish growth, unemployment and decreasing tax revenue. In anticipation of these effects and their electoral and fiscal consequences, policymakers tend to carefully avoid any policy that affects the revenue prospects of business. Instead, they are concerned with maintaining business confidence. As a result, the political preferences and economic interests of business enjoy over-proportionate consideration in the formulation and implementation of public policy, even if business abstains from direct political activity. Furthermore, this mechanism is not confined to redistributive politics. Studies on regulatory policies, from safety regulation on drugs (Peltzman, 1973) to car fuel economy standards (Sunstein, 1998, pp. 234-6) have shown that the unintended effects of policy can render measures of public policy inefficient, reverse their intended effects, or even prevent their very formulation should policymakers anticipate adverse reactions from business. As the principal underlying mechanism is the same for distributive and regulatory policies, we hereafter refer to structural constraints on public decisionmaking in any policy area as negative inducement effects.

Yet, theories of structural domination have their own problems. From an empirical vantage, if the structural power thesis holds, we should rarely witness policy 
change over time that overrides business's political preferences. However, instances of business failing in the policy struggle are frequently observed (Mitchell, 1997; Smith, 2000). Moreover, structural dependence theories cannot accommodate the ubiquitous political activity of business. The question inevitably arises as to why, if their interests are automatically taken care of, capitalists would waste time and money on politics in the first place. ${ }^{3}$ From a theoretical viewpoint, the assumption that democratically elected policymakers face only the kind of constraints transmitted by the electoral effects of macroeconomic performance seems unrealistic. Because politicians use ideology as an efficient way to communicate their goals and platforms to voters, they are compelled to be somewhat ideologically consistent (Downs, 1957, pp. 110-12). For the sake of their credibility and reputation, both are invaluable assets in electoral competition, elected officials have strong incentives to adhere to their ideological self-labeling and to deliver on their preelection pledges (McGann, 2002, pp. 51-7).

The distinction between intentional versus unintentional explanations is an idealtypical one, and numerous studies have implicitly or explicitly drawn on ideas from both sides. Policy network analysis, for instance, views the political involvement of business primarily as the developing and maintaining of close relationships with the relevant branches of government and with other agents who have common stakes in a policy area. In this approach, public policy-making is often seen as decisionmaking of interdependent, 'public' and 'private' actors who engage in exchange relations (for an overview, see Thatcher, 1998). With respect to business power, several studies have pointed to the privileged access of business actors to policymakers (for example Knoke et al., 1996). This, however, is an empirical finding the explanation of which is beyond the scope of the policy network approach. Alternatively, Mitchell (1997) formulates a theory of 'calculated heroism' to explain why, given their structurally privileged political position, business interests may nevertheless incur political loss. Facilitated by external events such as scandals or environmental disasters, policymakers can sometimes embark on an escapade of 'calculated heroism' and temporarily override the business confidence factor and its electoral implications (Mitchell, 1997, pp. 167-217). While Mitchell's theory goes some way toward explaining why a policy may carry despite business' political opposition, it relies heavily on exogenous shocks.

In the following sentences, we outline how we believe a more systematic account of business's political power and its limits can be formulated. Our point of departure is the observation that some, but not all policies will lead to negative inducement effects. Yet, from a business perspective even low-cost policies entail costs. As part of their overall efforts to minimize costs, firms permanently strive to reduce the regulatory uncertainty permeating their operational environment (Birnbaum, 1984). Businesses, therefore, tend to hedge their bets and regularly assess new policies from a primarily conservative perspective. According to one lobbyist:

It's not about being negative for the sake of it all the time. But there are plenty of cases where [we] would be very cautious. Sometimes, it may be that what ultimately came out of the whole process might not have been as bad as first was foreseen, but I guess it's because people overestimated it genuinely. ${ }^{4}$ 
Accordingly, business lobbyists have incentives to misrepresent the size and likelihood of a policy's negative inducement effects. The problem for policymakers is that they often lack the information necessary to assess the accuracy or veracity of business' predictions. While policymakers may well be aware of general structural constraints ('it's the economy, stupid!'), they will often be less clear about what exactly it is that business needs in a given situation and with respect to particular policy areas. By contrast, much of the information required for the assessment of negative inducement effects is routinely available to business and its interest organizations. Special interest groups enjoy informational advantages vis-à-vis policymakers due to the latter's capacity constraints, and because of interest groups' own strong incentives to pool resources and routinely conduct research on issues of concern to their members. If the special interest group in question is business, this informational asymmetry is greater. Individual firms accumulate knowledge about relevant policy issues in the course of performing their everyday activities. Businesses thus automatically possess data about costs, demand or technological expertise as private information that is important for political decisionmaking. In the words of one lobbyist:

I am actually surprised how often [ministerial civil servants] ring me up looking for information I would have assumed they would have at their fingertips. Maybe it's just a matter of us having access to several thousand members, and [the members] trust us, so we survey them. I think we are a good source of reliable data. ${ }^{5}$

Therefore, in contrast to previous studies of interest group influence (for example Austen-Smith, 1993), we assume that being informed is costless for business. ${ }^{6} \mathrm{Nev}-$ ertheless, there are countervailing constraints on the making of exaggerated claims, because business representatives have a strong, long-term interest in maintaining their reputation as suppliers of good information (Berry, 1989, pp. 143-6). As a German public affairs executive emphasized:

If we did some scaremongering with figures that could in retrospect be dismantled by other research institutes, we would maneuver ourselves off the pitch because nobody would believe us anymore. Where I work, I don't think this bargaining scenario of 'ask for 100, take home 50' really applies. $^{7}$

Thus, we assume that when devising a lobbying strategy, business will be careful to avoid situations in which wildly exaggerated predictions can be exposed as such. We further assume that business lobbyists attempt to make their messages credible by underlining their resolve with costly campaigning. Our model deviates from previous signaling models by considering the reputational costs of 'lying' as well as the material costs of lobbying. Because policymakers know that business lobbyists are self-interested, they are suspicious of the possibility of misrepresentations. It is therefore not sufficient for business to reiterate variations of the old mantra that 'what's good for the United States is good for General Motors, and vice versa. ${ }^{8}$ As both 'types' of businesses, those severely affected as well as those on whom the policy imposes only minor costs, share an interest in having the policy removed from the agenda, the problem for the policymaker is that she does not know which type of lobbyist she is dealing with. In this situation of a partial conflict of 
interests between business and government, a signaling game ensues in which a lobbyist 'reminds' the policymaker that she is structurally dependent on business, while the policymaker is aware that the relevance of this dependence varies according to a parameter that is unknown to her: whether or not the pending policy leads to negative inducement effects.

\section{A Signaling Model of Business Lobbying}

In the model, there are two actors, a business lobbyist $B$ and a policymaker $G$, and a pending policy proposal that may (or may not) induce significant negative effects on the part of the regulated firms. The game then proceeds as follows. Nature chooses whether a pending policy will induce negative effects $\left(t_{1} \in T\right)$ with probability $\theta_{1}$, or not $\left(t_{2} \in T\right)$ with probability $\theta_{2}=1-\theta_{1}$, and reveals its move to the business lobbyist, but not the policymaker. Privately informed about the state of the world, the business lobbyist sends a costly message (signal $s_{1}$ ) to the policymaker to inform her decision, or refrains from doing so (signal $\left.s_{2}\right)$. The policymaker can take one of two actions, pass the policy in question $\left(a_{1}\right)$, or retain the status quo $\left(a_{2}\right)$. The resulting payoffs for the policymaker and for business depend on which of the two states of the world is realized. In $t_{1}$, the policy has severe negative effects of size $\alpha$ on business. Also in $t_{1}$, the policy backfires or negatively affects the country's macroeconomic performance and thereby the policymaker's ability to achieve her various other policy goals (Block, 1977, p. 15), or to gain another term in office at the next election (Lewis-Beck and Stegmaier, 2000). The negative inducement effects for the policymaker are represented by $u$.

Regardless of the state of the world, if the policymaker chooses $a_{2}$ she incurs a decline in credibility and reputation and will be punished at the next election for cheating on her policy pledges and selling out to big business. We denote these pledge costs by $p$. Business incurs minor policy costs of size $\beta$ in situation $t_{2}$, but is relieved of all costs except any material lobbying costs $l$ if the policymaker complies with its lobbying demands $a_{2}$. However, if it turns out that business duplicitously sent $s_{1}\left(s_{2}\right)$, it will incur an exogenous penalty for lying $k$, which can be interpreted as being denied access to the policymaker for future representations. Throughout what follows, we assume that misinformation can only be detected once the policymaker has passed the policy. We deal with the more general setting, where costs for lying occur whenever business sends the wrong signal, in Appendix 2. Finally, while the policymaker can, to some extent, infer the credibility of the claims from the observed levels of costly political action business is willing to employ in the lobbying process, there are limits to playing tough and enticing business into showing its teeth. As research on the economic effects of regulation has shown, expectations about regulatory regime change can be just as important for the behavior of firms as the actual regulatory change itself (Binder, 1985; Granato, 1996). Open disputes over contested legislation can have negative effects on investment, conferring on the policymaker a 'confidence $\operatorname{cost}^{\prime} v$ whenever business decides to lobby. The payoffs are summarized in Table $1 .^{9}$

To investigate the interaction between the policymaker and the business lobbyist, the game is analyzed using the concept of perfect Bayesian equilibrium (PBE). We first introduce some additional notation. For the action set $S=\left\{s_{1}, s_{2}\right\}$ of business, 
Table 1: Payoffs of the lobbying game (business lobbyist, policymaker)

$\alpha>\beta>0$ and $u, v, p, k, l>0$

\begin{tabular}{|l|ll|l|ll|}
\hline$s_{1}$ & $t_{1}$ & $t_{2}$ & $s_{2}$ & $t_{1}$ & $t_{2}$ \\
\hline$a_{1}$ & $-\alpha-l_{1}-u-v$ & $-\beta-l-k,-v$ & $a_{1}$ & $-\alpha-k,-u$ & $-\beta, 0$ \\
$a_{2}$ & $-l_{1}-v-p$ & $-l_{1}-v-p$ & $a_{2}$ & $0,-p$ & $0,-p$ \\
\hline
\end{tabular}

let $\Delta(S)$ denote the set of probability distributions over $S$ so that a strategy for business is a function $q: T \rightarrow \Delta(S)$. Denote the probability that business sends the message $s$ given the type $t$ by $q(s \mid t)$. Accordingly, a strategy for the policymaker is a function $r: S \rightarrow \Delta(\mathrm{A})$ assigning a probability distribution to any signal $s$ that the policymaker receives from business; we write $r(a \mid s)$ for the probability that the policymaker takes action $a$ given the signal $s$. Finally, let $\mu(t \mid s)$ denote the policymaker's posterior belief that business is of type $t$ given that she has received signal $s$. A PBE of the lobbying game then is a strategy-belief triple $\left(q^{*}, r^{*}, \mu^{*}\right)$ such that (Fudenberg and Tirole, 1991):

(i) for any $t \in T: q^{*}(\hat{s} \mid t)>0 \quad$ if $\hat{s} \in \underset{s \in S}{\arg \max } U_{B}(x, r *(s), t)$

(ii) for any $s \in S: r^{*}(\hat{a} \mid s)>0 \quad$ if $\quad \hat{a} \in \underset{a \in A}{\arg \max } U_{G}(s, a, \mu *(s))$

(iii) for any $s \in S$ such that $\sum_{t \in T} q^{*}(s \mid t)>0, \mu^{*}(s)$ satisfies

$$
\mu *(\hat{t} \mid s)=\frac{q^{*}(s \mid \hat{t}) \theta(\hat{t})}{\sum_{t \in T} q^{*}(s \mid t) \theta(t)} .
$$

Condition (i) requires that for any type $t$ of business his strategies $q^{*}$ must be optimal with respect to the utility function $U_{B}$ given the strategy $r^{*}(s)$ of the policymaker. Condition (ii) states that the policymaker's strategy $r^{*}(s)$ maximizes her expected payoff $U_{G}$ given the posterior beliefs about the type of business. Condition (iii) requires the posterior beliefs to satisfy Bayes' rule whenever possible. ${ }^{10}$

In the following propositions we present the equilibria of the lobbying game. In a separating equilibrium the two possible types of lobbyists send different messages and the policymaker, having observed the signal, can infer the state of nature with certainty. Consequently, her updated belief coincides with the true type of business. In a semi-separating equilibrium, a lobbyist who suffers negative inducement effects sends a signal $s_{1}$ to the policymaker, whereas a lobbyist who is not affected randomizes between the signals $s_{1}$ and $s_{2}$. In a pooling equilibrium of type I, all types of lobbyists send the same message $s_{1}$ claiming negative inducement effects of the pending policy. Finally, in a pooling equilibrium of type II, both types of lobbyist refrain from action, that is they 'send' signal $s_{2}$. In neither situation can the policymaker learn anything from the message and her beliefs do not change after receiving the signal. 
Figure 1: Equilibria of the lobbying game

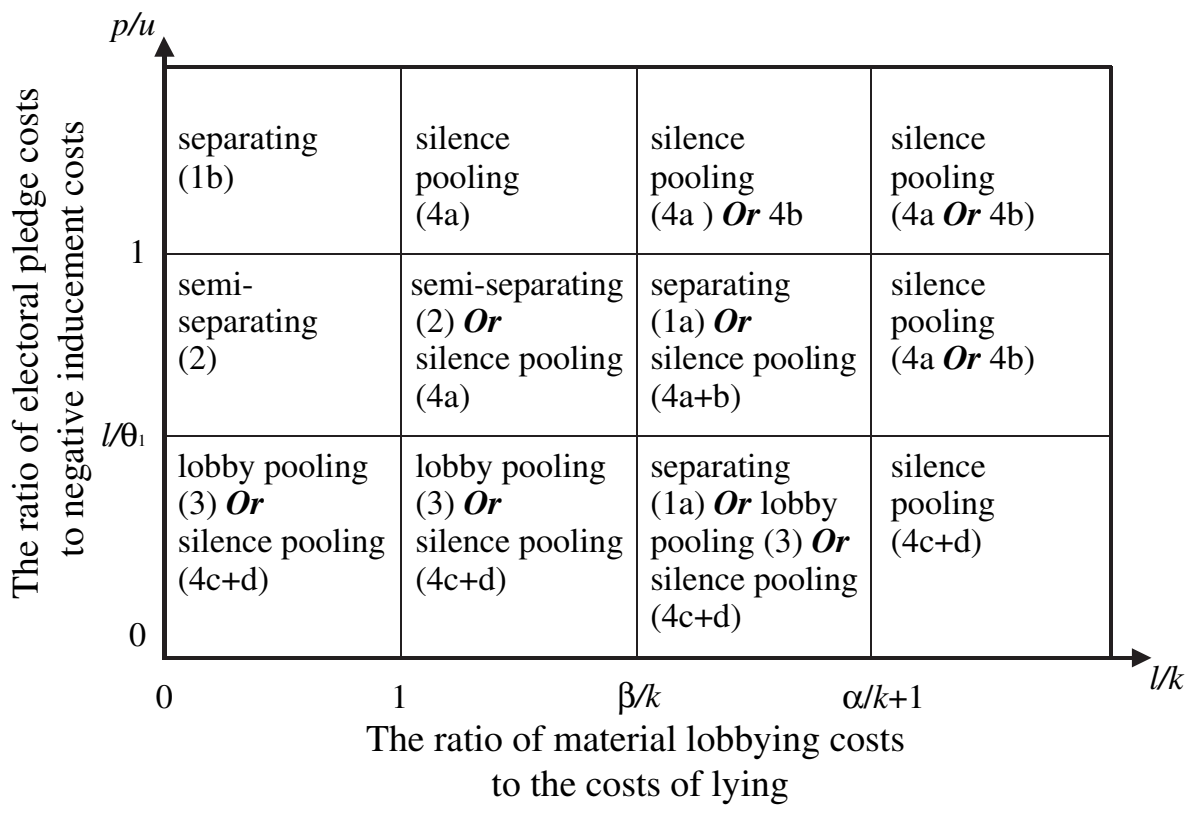

Explanatory note: In each of the squares shown the main labels give the type of equilibria that are possible there: sometimes only one equilibrium is feasible, at other times a range of equilibria are possible. The numbers given in brackets after each type of equilibrium refer to the Proposition numbers in the accompanying main text-please refer to the appropriate passage for a fuller explanation.

In these principal situations nothing is said about the policymaker's response to either pass the regulation or pull back and retain the status quo. In the following propositions we show that the behavior of the lobbyist and the policymaker's response both depend on two parameters, the ratio of material lobbying cost to the costs of being caught lying, and the ratio of (electoral) pledge costs to (economicelectoral) negative inducement costs. All proofs appear in the appendices. Figure 1 summarizes the findings. ${ }^{11}$

Proposition 1: There is a separating PBE

a) if $\beta / k<l / k<\alpha / k+1$ and $p / u<1$ :

$$
\left(\left(s_{1}\left|t_{1}, s_{2}\right| t_{2}\right),\left(a_{2}\left|s_{1}, a_{1}\right| s_{2}\right),(1,0)\right) ;
$$

b) if $l / k<1$ and $1<p / u$ :

$$
\left(\left(s_{1}\left|t_{1}, s_{2}\right| t_{2}\right),\left(a_{1}\left|s_{1}, a_{1}\right| s_{2}\right),(1,0)\right) .
$$

In the first case (la), pledge costs are smaller than negative inducement costs, so that the policymaker has an incentive to be responsive to the signal sent by business: she withdraws the proposal if business signals severe adverse effects but passes the regulation if the lobbyist remains silent. The lobbyist, on the other hand, is 
marked by a balanced ratio $l / k$ of the (material) costs of lobbying to costs of lying such that informative lobbying is indeed in equilibrium. In the second case (lb), the policymaker expects relatively high pledge costs from retaining the status quo and consequently always passes the regulation whatever the signal is. Here, the lobbyist still separates as the costs for lying exceed the material lobbying costs. Thus, if pledge costs are high, the separating behavior on the side of the lobbyist can be in equilibrium even if the costs for lobbying are low.

Proposition 2: There is a semi-separating PBE if $l / k<\beta / k$ and $\theta_{1}<p / u<1$ :

$$
\left(\left(s_{1}\left|t_{1},\left[s_{1}, y ; s_{2}, 1-y\right]\right| t_{2}\right),\left(\left[a_{1}, x ; a_{2}, 1-x\right]\left|s_{1}, a_{1}\right| s_{2}\right),(\pi, 0)\right),
$$

where $y=\frac{\theta_{1}(u-p)}{p \theta_{2}}, x=\frac{\beta-l}{\beta+k}$, and $\pi=p / u$.

According to Proposition 2, if the policymaker's cost ratio is at a moderate level but the business lobbyist's minor policy costs exceed those for lying, both actors play mixed strategies in equilibrium. If business is severely affected by the proposed regulation, it will send the corresponding signal with certainty. Otherwise, business has the incentive and the ability to misrepresent, where the probability for misrepresentation is increasing in the negative inducement $\cos t s u$, but decreasing in the pledge costs $p$.

Proposition 3: There are pooling PBE of type I if $l / k<\beta / k$ and $p / u<\theta_{1}$ :

$$
\left(\left(s_{1}\left|t_{1}, s_{1}\right| t_{2}\right),\left(a_{2}\left|s_{1}, a_{1}\right| s_{2}\right),\left(\theta_{1}, \pi\right)\right), \quad \text { where } \pi<\min \{p / u, 1\} .
$$

In a pooling equilibrium of type I, the lobbyist always claims to be severely affected. This only happens if both cost ratios are small, that is when there is little incentive to misrepresent on the side of the lobbyist and only a weak incentive not to withdraw the proposal on the side of the policymaker.

Proposition 4: There are pooling PBE of type II

a) if $l / k>1$ and $\theta_{1}<p / u$ :

$$
\left(\left(s_{2}\left|t_{1}, s_{2}\right| t_{2}\right),\left(a_{1}\left|s_{1}, a_{1}\right| s_{2}\right),\left(\pi, \theta_{1}\right)\right), \quad \text { where } \pi<\min \{p / u, 1\} ;
$$

b) if $l / k>\max \{\alpha / k+1, \beta / k\}$ and $\theta_{1}<p / u$ :

$$
\left(\left(s_{2}\left|t_{1}, s_{2}\right| t_{2}\right),\left(a_{2}\left|s_{1}, a_{1}\right| s_{2}\right),\left(\pi, \theta_{1}\right)\right), \quad \text { where } p / u<\pi<1 ;
$$

c) if $p / u<\theta_{1}$ :

$$
\left(\left(s_{2}\left|t_{1}, s_{2}\right| t_{2}\right),\left(a_{2}\left|s_{1}, a_{2}\right| s_{2}\right),\left(\pi, \theta_{1}\right)\right), \quad \text { where } p / u<\pi<1 ;
$$

d) if $p / u<\theta_{1}$ :

$$
\left(\left(s_{2}\left|t_{1}, s_{2}\right| t_{2}\right),\left(a_{1}\left|s_{1}, a_{2}\right| s_{2}\right),\left(\pi, \theta_{1}\right)\right), \quad \text { where } \pi<\min \{p / u, 1\} .
$$

According to Proposition 4, there are four sub-cases of pooling equilibria of type II when the lobbyist refrains from sending a costly message. In the first three situations, lobbying costs exceed the costs of lying so that the lobbyist has no incentive to send a costly message whatever the state of the world. The policymaker's 
equilibrium response to such 'silence' is to pass the regulation if the pledge-toeconomic-costs ratio is considerably high $(4 a, 4 b)$ and to retain the status quo if the ratio is reasonably low $(4 \mathrm{c}, 4 \mathrm{~d})$. In the latter case, a low cost ratio for the policymaker induces a pooling II equilibria with a compliant policymaker, whatever the cost ratio for the business lobbyist.

In the following sections, we predict outcomes of two real-world lobbying games by reference to the values of the variables that determine the lobbying equilibria in our formal model: the relative size of the reputation constraints of business in relation to the costs of lobbying $(l / k)$, and the ratio of the policymaker's reputation costs from pre-election policy commitments to the electoral costs from adverse economic effects $(p / u)$. In empirical applications of formal signaling models, microlevel case studies can serve as quasi-experiments in which the central deductive claims of the theory are put to a test (see Kennan and Wilson, 1993, p. 54; Morton, 1999, pp. 133-5). We have selected two cases on the values of the key explanatory variables such that the crucial parameter constellations of Propositions $\mathrm{lb}$ and 3 , that is, those identifying the equilibria in which lobbying takes place at least some of the time, are represented. ${ }^{12}$

\section{Case Study I: Regulating Small Business Banking in England and Wales}

In 1998, the British Chancellor of the Exchequer, Gordon Brown, asked Don Cruickshank, a former Director at the Office of Telecommunications, to conduct an independent review of competition in banking services in the United Kingdom. In his report, Cruickshank found that a 'complex monopoly' and pricing collusion existed among the four largest high street banks in England and Wales (Barclays Bank plc, HSBC Bank plc, Lloyds TSB Bank plc, and National Westminster Bank) enabling them to secure almost 90 percent of the market in small business banking and to realize excess profits of $\$ 525 \mathrm{~m}$ a year between them (Cruickshank, 2000). The findings were deemed sufficiently serious by the Chancellor to refer the matter to the Competition Commission. After a two-year investigation, the Commission agreed with Cruickshank on most aspects and concluded that the practices of the four banks were against the public interest (Competition Commission, 2002). Based on these reports, the government set out regulatory measures to encourage competition and curb the excess profits. The measures required that the four banks offer to all small- and medium-sized enterprises (SMEs) with current accounts in England and Wales an account that pays interest at Bank of England base rate less 2.5 percent, alternatively to offer SMEs accounts free of money transmission charges, or a choice between the two options (Competition Commission, 2002, p. 5). As a result of these remedies, the banks would sacrifice an annual slice of their profits of over $\$ 100 \mathrm{~m}$ each. The banks argued that the regulation might end up harming rather than helping SMEs. According to the British Bankers' Association, the measures could undermine the potential competitors' attempts to break into the market, as part of their unique selling point was paying interest on SME current accounts (Financial Times, March 21, 2002). The banks further pointed out that price controls might result in the banks trying to recoup some of the costs by increasing charges elsewhere, for example by raising the price of loans to SMEs (Guardian, March 15, 2002). 


\section{Pledge Costs $(p)$}

From the publication of the Cruickshank report onward, the government explicitly committed itself to address the problems identified therein (HM Treasury, 2004, pp. 68-9). In his 2000 Budget speech, Brown announced 'major reforms ... to open up competition in banking' (HM Treasury, 2000). In March 2002, he stated that his goal was 'to create a fully competitive environment where new entrants can compete with existing banks on a fair basis and can offer more competitive banking services for small businesses' (Department of Trade and Industry, 2002). On the same day, the Secretary of State for trade and industry, Patricia Hewitt, released a press statement vowing that in the future, 'SMEs should find it easier to switch banks, charges should be lower and more transparent and SMEs should have greater choice both within and between banks' (Department of Trade and Industry, 2002). Thus, the Labour government could expect considerable reputation costs if it threw out the policy. The banks shared this view. According to a senior manager at HSBC, the entire process of tackling banking practices in the SME retail market was designed to be a 'vote winner'. ${ }^{13}$

\section{Negative Inducement Effects (u)}

After hearings in May and June 2002, the Treasury Select Committee echoed the banks' view that the policy 'could damage rather than improve SME financing, and could well deter entry of the smaller banks into SME lending' (House of Commons, 2002, p. 22). However, the Competition Commission related the banks' capital base and allocation of capital to services to SMEs to their operating profits and cost of equity and found that the returns generated by the banks' SME business were at least seven percentage points above the average cost of equity of fifteen percent. These findings decisively contradicted the banks' claims of negative inducement effects. According to the commission's report, '[the] remedy ... in no way adversely affects the terms on which banks lend to their customers' (Competition Commission, 2002, p. 157). Thus, facing considerable pledge costs combined with rather small expected policy costs, the government had sufficient grounds to call the bluff and show itself determined not to buy the banks' predictions of negative inducement effects.

\section{Material Lobbying Costs (1)}

At the height of the controversy, the Federation of Small Businesses, feared that, 'the big four banks have huge resources at their disposal', and that their combined lobbying power may bring 'the whole process off the rails' (ePolitix, 2002). As it turned out, the banks actually spent very little on fighting the policy. A senior manager at HSBC estimated that the actual lobbying costs incurred by HSBC amounted to less than $\$ 20,000$ during the eighteen-months period when the Competition Commission was investigating. This sum breaks down primarily into management time and the preparing of press interviews and other media representations. ${ }^{14}$ He characterized the banks' lobbying effort as 'overall muted' and a 'mere sideshow.' None of the other banks went any further in their efforts. 


\section{Reputation Costs (k)}

According to the traditional wisdom in the literature on financial service regulation in Britain, an unwritten contract exists between successive governments and the banks designed to maintain public confidence in the banking system (Grant, 1993, pp. 69-70; Le Fanu, 2004). This relationship of trust has shaped communication and interaction within the 'City-Treasury-Bank nexus' (Grant, 1993, p. 69) since the incorporation of the Exchequer into the Department of Economic Affairs in 1947. While it may have been somewhat weakened by the Cruickshank report, this relationship would not easily be sacrificed for the short-term gains of about $\$ 100 \mathrm{~m}$ for each of the four banks. A senior manager at HSBC acknowledges that more avid lobbying against the regulation would have been pointless, and may have hurt the relationship between the banks and the Treasury. ${ }^{15}$ Thus, relative to their material lobby costs, the banks' reputation costs of jeopardizing the timehonored and carefully nurtured relationship of trust with the Treasury were high.

Given these relations ( $p>u$ and $l<k$ ), we expect a separating equilibrium according to Proposition $1 b$, in which the policymaker is resolute and presses ahead with the regulation while the business lobbyist, unwilling to bear high reputation costs, separates and refrains from making false claims.

\section{Outcome}

Through its initial assertions of negative inducement effects, the banking lobby managed to procrastinate the regulatory process and cash in on excess profits while they lasted. Yet, beyond this rhetoric at cheap talk level, the banks abstained from engaging in a political campaign that would underscore the likelihood of the policy's asserted negative inducement effects. Only scant strategic coordination took place among the banks. Consequently, the banks soon backed down, reaching a binding agreement with the government on July 19, 2002, under which they can choose between providing free money transmission services to their SME customers and paying interest on current accounts. In a further agreement reached on October 31, 2002, the banks committed to undertake measures to ease account switching and increase transparency of charges (HM Treasury, 2002). According to a manager at HSBC, the banks had concluded at an early stage that any further lobbying would ultimately not be worth their while: 'Did we really think we would influence the outcome? Not really. ${ }^{16}$

\section{Case Study II: Phasing Out PVC Components in Hesse, Germany}

In August 1992, Jörg Jordan, the Building Minister of the governing coalition of Greens and Social Democrats (SPD) in the German state of Hesse, enacted a technical directive according to which future social housing projects would be free of polyvinyl chloride (PVC). ${ }^{17}$ As of January 1993, the directive banned PVC-based materials such as water and sewage pipes, and floor and wall coverings from public contract awards. A transition clause stipulated the phasing out of PVC-based doors and windows from public calls for tenders beginning on January 1, 1995. This gave the construction and supply industry four months and twenty-eight months, respectively, to adjust to the new requirements. By May 1993, the PVC- 
manufacturing and processing industry demanded that the regulation be dropped immediately, arguing that it would lead to considerable disinvestments and redundancies (Die Tageszeitung, July 23, 1993).

\section{Pledge Costs (p)}

From its inauguration, the governing coalition has developed a strong profile on environmental policy, which included the implementation of principles of precautionary and sustainable substance policy (Die Tageszeitung, July 23, 1993). With this policy, the government catered for the steady and increasing demand among the electorate for environmental protection and the limitation of health and safety hazards. Throughout the 1980s, chlorine-based products such as PVC hazards attracted considerable levels of negative publicity (Darimont, 1995, p. 285). PVC is responsible for the release of dioxins and other toxic substances in the event of fires; it increases the technical and financial burden on waste removal; and a plethora of complex additives renders many PVCs unsultable for recycling. Thus, the coalition had strong incentives to deliver on its promises relating to the environment. The phaseout of PVC from public construction was an obvious and non-contentious starting point, or so the government thought at the time.

\section{Negative Inducement Effects (u)}

The production and processing of PVC accounts for a large portion of chemical manufacturing in Germany, where in 1992 approximately $1.5 \mathrm{~m}$ tons of PVC were produced (Nolte and Joas, 1995, p. 67). The construction industry is the largest single user of PVC, making up almost half of total demand (Umweltbundesamt, 2001). A comprehensive study by a Swiss consulting firm found that a large percentage of PVC uses could be substituted cost-effectively (that is, at no or very little net increase in costs) and with a potential increase in employment of four percent (Prognos AG, 1994, pp. II-256-63). Windows and cables comprise the more costly segment, with replacement costs of up to 36 percent. But all remaining construction inputs (floorings, pipes, etc.) can be substituted very cost-efficiently. In the area of public construction contracts, the net cost effect of the substitution of PVC with alternative materials would amount to a two percent increase on per-unit costs of social housing. This increase is lower than the usual fluctuations on bids and costs in the construction industry. Furthermore, the directive only referred to PVC used in social housing, which constitutes a segment of less than fifteen percent of the total construction market in Hesse. Finally, as the Social Democratic MP Sieghard Pawlik pointed out at the time, this two percent increase would not have impacted on the incumbent government's plans for social housing construction contracts (Messischer Landtag, PlPr. 13/068, 16 June, 1993).

The directive would have affected five large and fifteen medium-sized enterprises, as well as around 300 small firms, in one way or another. Larger firms would have been affected only marginally, as PVC processing was a minor part of their activities (Jacob, 1999, p. 38). The smaller firms, such as building contractors and material purveyors, faced compliance costs arising from the need to switch to alternative materials (Hanauer Anzeiger, June 21, 1993). Yet, while the proposed regulation would not have had the severe negative impact claimed by the industry, the government's expectation of the impact of such effects was immense and exacerbated 
by an overall unfavorable economic situation. For example, in May 1993, unemployment was at 167,000 , a 28 percent increase on the same month of the previous year. Thus, the government's overall $p / u$ ratio remained small $\left(p / u<\theta_{1}\right)$.

\section{Policy Costs $(\beta)$}

Vinyl siding and windows have been the fastest-growing uses of PVC (and the largest after pipes), experiencing double-digit annual growth rates throughout the 1980s (Ackerman and Massey, 2003, p. 33). Yet, much more was at stake for Germany's chlorine industry than the continuation or discontinuation of the use of PVC components in Hesse's public housing projects. Industry representatives feared that a ban of these materials from public contracts in one state would set a precedent opening the floodgates for further regulatory inroads into PVC use in other German states and, ultimately, at the federal level. ${ }^{18}$ The sector had already been beleaguered during the early years of the 1990s, when the total volume of chlorine going into chlorinated products increased only marginally. A standstill or drop in the demand for chlorine had the potential of creating long-term problems for the entire chemical industry. The Germany-based, but globally operating, firms Bayer AG, BASF Group and the former Hoechst AG, for instance, rely heavily on the chlorinated polymer industry to absorb the millions of tons per annum of hydrochloric acid, a byproduct of many production processes (Nolte and Joas, 1995, pp. 17-38). At the same time, the European chlorine industry's rationalization processes resulted in plant closures in Scandinavia, Italy and the UK (Darimont, 1995), thus sensitizing Germany's chemical industry to unfriendly political developments. Due to concurrent developments such as the recession of the early 1990s, the ban on chlorofluorocarbon, the declining demand for chlorinated solvents, and the partial replacement of domestically produced PVCs by cheaper imports, annual primary chlorine production in Germany decreased by fifteen percent from $3.4 \mathrm{~m}$ tons in 1989 to $2.9 \mathrm{~m}$ tons in 1993 (Darimont, 1995, pp. 285-6). Thus, while the directive caused very little harm to either Hesse's construction industry or Germany's chlorine industry, the latter perceived the Hesse PVC phaseout as a first battle within a much larger war over the future standing of PVC. We thus consider both $\alpha$ and $\beta$ to be substantial.

\section{Material Lobbying Costs (1)}

In May and June 1993, the industry's campaign against the directive employed all means available to resolute lobbyists. It is impossible to quantify the costs of this campaign. ${ }^{19}$ Instead, it should suffice here to point out that the chemical workers' demonstrations in Wiesbaden, the state's capital, and other Hessian locations alone were very costly endeavors. The protests took place on Mondays and involved several thousand protesters turning out on paid leave on at least three occasions. This implies deadweight labor time losses of between $€ 500$ and $€ 1 \mathrm{~m}$. Nevertheless, even a lobbyist willing to invest in a costly political campaign would have faced only moderate costs as compared to the long-term costs of a policy for which this particular directive could have been a mere precedent. We thus conclude that $l<\beta$. 
It is at this point that the interactive nature of the signaling game is most relevant. Because of her small $p / u$ ratio, the policymaker was very receptive to the lobbyist's arguments, who in turn could exploit her sensitivity to his advantage and expect to get away with a bluff if it is of type $\left(t_{2}\right)$. With $p / \mathcal{u}<\theta_{1}$ and $l<\beta$, we expect a pooling equilibrium of type $\mathrm{I}$, in which the lobbyist always claims to be severely affected and the government backs down (Proposition 3).

\section{Outcome}

In a vigorous lobbying campaign coordinated by the public affairs organization of the PVC producers and processors, the Arbeitsgemeinschaft PVC und Umwelt, the industry predicted up to 10,000 job losses (Wiesbadener Tagblatt, June 15, 1993). This bold assertion, combined with increasing levels of publicity attached to the issue, convinced the government parties to look at the matter again and with more scrutiny, while the opposition parties scheduled a special hearing before the parliament's Committee on Building and Urban Planning in early June. The industry increased the pressure, and in mid June 1993, Hesse witnessed one of the most vigorous political campaigns of the state's post-war history. The firms and employers' organizations convinced the chemical workers trade union that slashing the directive was vital for the future employment of its members and even managed to get the building material purveyors and building contractors on board (Die Tageszeitung, July 23, 1993). Thus, the scene was set for mass rallies, the biggest of which was on June 14, 1993. In the main square in Wiesbaden, outside Hesse's parliament, 6,000 workers from the chemical and plastics industry turned out to demonstrate against the directive (Frankfurter Allgemeine Zeitung, June 15, 1993). In addition, the AgPU inundated MP's desks with brochures and even a purposelaunched periodical, and coordinated full-page advertisements in the regional press, all of which hammered home the economic disaster associated with the PVC phaseout (Die Tageszeitung, November 11, 1993). By late June rifts ensued between the Greens and the Social Democrats (Wiesbadener Tagblatt, June 30, 1993). Eventually, the Greens gave in. On July 22, a compromise bill was debated and passed in parliament. ${ }^{20}$ Later, with two months hindsight, Prime Minister Hans Eichel (SPD) commented, 'the preservation of jobs had to have priority' (Hersfelder Zeitung, September 16, 1993).

\section{Discussion and Conclusions}

We have developed a model of lobbying that pays explicit attention to what is special about business as a political actor: the social and political relevance of its private decisions on investment and allocation, and its first-hand access to information essential for public policymaking. The model identifies two variables that jointly predict equilibrium outcomes: the reputation constraints of business in relation to the material costs of lobbying, and the ratio of the policymaker's reputation costs of defecting from policy commitments to expected negative inducement effects. Our analytical results suggest that, despite an informationally and structurally privileged position, business sometimes has little choice but to back down and bear the costs of policy for the sake of preserving its good reputation as an advisor to political actors. This implies that policymakers sometimes have more room for maneuver than they believe they do. 
Our case studies are consistent with the predictions of the formal model. They refer to two equilibrium outcomes, one in which the lobbyist tells the truth about the state of the world, and another in which the high ratio of policy costs to material lobbying costs generates incentives for lying. Both outcomes are difficult to explain using other approaches to the study of business political power. In the first case, a policy network approach would propose a victory for the banks, which have traditionally enjoyed a privileged existence in the City-Treasury-Bank policy community (Grant, 1993, pp. 69-76). Likewise, theories of structural power would have led us to expect that the banks carry the day due to their structurally privileged position regarding the implementation of the policy. Turning to the case of PVC phaseout, high levels of publicity emphasized by pluralist models (see Gormley, 1983; Mitchell, 1997, pp. 191-7), along with a lack of compelling structural constraints, would have warranted a prediction of business failure by both pluralist and structuralist theories. Network analysis may well have produced inconclusive results depending on whether the traditional policy community involving the chemical industry is emphasized (Grant, Paterson and Whitston, 1988), or its discontinuity due to the presence of a Green party coalition partner. Because of its explicit treatment of information asymmetry, our model enables us to explain why the Hesse government decided to withdraw the policy even though it would not have led to the negative inducement effects that were predicted by business. The high expected costs that might have occurred if the industry's predictions were truthful would have been damaging to the government. Faced with rising unemployment and a business community that behaves convincingly as if the situation was critical, the Hessian government was willing to heed the industry's warnings.

Our model of business political power has numerous observable implications amenable to quantitative empirical tests. Firstly, if the negative inducement effects of a policy in $t_{1}$ work through the causal link of economic voting, as postulated by our model, we would expect concessions by policymakers to be more likely in countries where economic indicators are strong predictors of electoral outcomes. Secondly, the reputational constraint on lobbyists is likely to be stronger with respect to policymakers who have traditionally maintained close relationships with the business community, thus discouraging business from making airy claims vis-à-vis right-leaning policymakers. Therefore, we expect left-leaning policymakers to be lobbied more frequently by business compared to their conservative counterparts. Thirdly, the likelihood of concessions should increase with the policymakers' dependence on business for data and expertise. In an empirical test, the dependent variable measures policymakers' concessions to business. Ideally, this variable would already have an inbuilt control for the salience of the regulatory issues at hand and thereby take account of pledge costs. This could be achieved by operationalizing the dependent variable as a pledge fulfillment rate measuring the ratio of policy pledges prior to the last election and the actual regulatory activity undertaken once the party or parties took office. Policy pledges and enacted policies can be extracted by content analysis from party manifestos and legal texts. The main independent variable in a large- $N$ study testing the findings generated in this paper, the degree of policymakers' informational independence, can be operationalized as the ratio of public research spending to total social 
research expenditure. Finally, if business has to worry about the consequences of misrepresentations, as our model stipulates, we should observe examples of policymakers punishing businesses that cried wolf by denying them access in the present. ${ }^{21}$

Throughout this paper, we have made a number of assumptions to simplify otherwise complex political realities. In the main, these assumptions relate to the number of actors and the informational resources available to the policymaker. In allowing for sources of information independent of the lobbyist, the case of small business banking points toward the domain boundaries of our model. It demonstrates the high level of government capacity that is possible when policymakers do not depend on information supplied by those regulated. The high-quality information provided by Cruickshank and the Competition Commission greatly reduced the information asymmetry in favor of the policymaker. It is ironic that this determination of policymakers who 'know better', a characteristic that has become firmly associated with successive Thatcher governments (see Richardson, 2000, pp. 1009-10), has found a recent incarnation in Labour's take on competition in small business banking. Future extensions of our model should therefore capture situations in which one or more countervailing lobbyists exist or where the policymaker can acquire independent information.

(Accepted: 14 September 2004)

\section{About the Authors}

Patrick Bernhagen, Department of Politics and International Relations, Edward Wright Building Dunbar Street, Aberdeen AB24 3QY,UK; email: p.bemhagen@abdn.ac.uk

Thomas Bräuninger, Department of Politics and Management and Center for Junior Research Fellows, University of Konstanz, Fach D 80, D-78457 Konstanz, Germany; email: Thomas. Braeuninger@uni-konstanz.de

\section{Appendix 1}

We provide a sample proof for the two equilibrium areas of the lobbying game described in Proposition 1. The proofs for the other equilibrium areas are similar and omitted for lack of space.

Proof of Proposition 1: Suppose the lobbyist plays the equilibrium strategy $m$ specified above. Given the policymaker's equilibrium beliefs $\mu^{*}(m)$, the expected utility of the policymaker then is:

$$
\begin{aligned}
& U_{G}\left(s_{1}, a_{1}, \mu *(m)\right)=-u-v, \quad U_{G}\left(s_{1}, a_{2}, \mu *(m)\right)=-v-p, \\
& U_{G}\left(s_{2}, a_{1}, \mu *(m)\right)=0, \quad U_{G}\left(s_{2}, a_{2}, \mu *(m)\right)=-p .
\end{aligned}
$$

Then $\left(a_{2}\left|s_{1}, a_{1}\right| s_{2}\right)$ is the dominant strategy if $p / u<1$, and $\left(a_{1}\left|s_{1}, a_{1}\right| s_{2}\right)$ is optimal if $p / u>1$. Now consider the initial choice of the lobbyist at the first stage.

Case (i): If the policymaker plays the equilibrium strategy $\left(a_{2}\left|s_{1}, a_{1}\right| s_{2}\right)$ and has equilibrium beliefs, the expected utility of the lobbyist becomes: 


$$
\begin{aligned}
& U_{B}\left(s_{1}, r *(m), t_{1}\right)=-l, \quad U_{B}\left(s_{2}, r *(m), t_{1}\right)=-\alpha-k, \\
& U_{B}\left(s_{1}, r *(m), t_{2}\right)==-l, \quad U_{B}\left(s_{2}, r *(m), t_{2}\right)=-\beta .
\end{aligned}
$$

Given the assumption $\beta / k<l / k<\alpha / k+1,\left(s_{1}\left|t_{1}, s_{2}\right| t_{2}\right)$ is the dominant strategy.

Case (ii): If the policymaker plays the equilibrium strategy $\left(a_{1}\left|s_{1}, a_{1}\right| s_{2}\right)$ and has equilibrium beliefs:

$$
\begin{aligned}
& U_{B}\left(s_{1}, r *(m), t_{1}\right)=-\alpha-l, \quad U_{B}\left(s_{2}, r *(m), t_{1}\right)=-\alpha-k, \\
& U_{B}\left(s_{1}, r *(m), t_{2}\right)==-\beta-k-l, \quad U_{B}\left(s_{2}, r *(m), t_{2}\right)=-\beta .
\end{aligned}
$$

Then $\left(s_{1}\left|t_{1}, s_{2}\right| t_{2}\right)$ is the dominant strategy only if $l / k<1$. Finally, using Bayes' rule, the posteriori beliefs of the policymaker along the equilibrium path are:

$$
\mu *\left(t_{1} \mid s_{1}\right)=1, \mu *\left(t_{2} \mid s_{1}\right)=0, \mu *\left(t_{1} \mid s_{2}\right)=0, \mu *\left(t_{2} \mid s_{2}\right)=1
$$

\section{Appendix 2}

In the case that costs for lying occur whenever business sends the wrong signal, the equilibria are:

Proposition $1^{\prime}$ : There is a separating PBE

a) if $\beta-k_{2}<l<\alpha+k_{1}$ and $p / u<1$ :

$$
\left(\left(s_{1}\left|t_{1}, s_{2}\right| t_{2}\right),\left(a_{2}\left|s_{1}, a_{1}\right| s_{2}\right),(1,0)\right)
$$

b) if $l<k_{1}$ and $1<p / u$ :

$$
\left(\left(s_{1}\left|t_{1}, s_{2}\right| t_{2}\right),\left(a_{1}\left|s_{1}, a_{1}\right| s_{2}\right),(1,0)\right) .
$$

Proposition 2': There is a semi-separating PBE if $l<\beta-k_{2}, k_{2}<\beta+k$ and $\theta_{1}<p / u<1$ :

$$
\left(\left(s_{1}\left|t_{1},\left[s_{1}, y ; s_{2}, 1-y\right]\right| t_{2}\right),\left(\left[a_{1}, x ; a_{2}, 1-x\right]\left|s_{1}, a_{1}\right| s_{2}\right),(\pi, 0)\right),
$$

where $y=\frac{\theta_{1}(u-p)}{p \theta_{2}}, x=\frac{\beta-l-k_{2}}{\beta+k-k_{2}}$, and $\pi=p / u$.

Proposition 3': There are pooling PBE of type I if $l<\min \left\{\alpha+k_{1}, \beta-k_{2}\right\}$ and $p / u<\theta_{1}$ :

$$
\left(\left(s_{1}\left|t_{1}, s_{1}\right| t_{2}\right),\left(a_{2}\left|s_{1}, a_{1}\right| s_{2}\right),\left(\theta_{1}, \pi\right)\right), \quad \text { where } \pi<\min \{p / u, 1\} .
$$

Proposition 4': There are pooling PBE of type II

a) if $l>k_{1}$ and $\theta_{1}<p / u$ :

$$
\left(\left(s_{2}\left|t_{1}, s_{2}\right| t_{2}\right),\left(a_{1}\left|s_{1}, a_{1}\right| s_{2}\right),\left(\pi, \theta_{1}\right)\right), \quad \text { where } \pi<\min \{p / u, 1\} ;
$$

b) if $l>\max \left\{\alpha+k_{1}, \beta-k_{2}\right\}$ and $\theta_{1}<p / u$ :

$$
\left(\left(s_{2}\left|t_{1}, s_{2}\right| t_{2}\right),\left(a_{2}\left|s_{1}, a_{1}\right| s_{2}\right),\left(\pi, \theta_{1}\right)\right), \quad \text { where } p / u<\pi<1 ;
$$


c) if $l>k_{2}$ and $p / u<\theta_{1}$ :

$$
\left(\left(s_{2}\left|t_{1}, s_{2}\right| t_{2}\right),\left(a_{2}\left|s_{1}, a_{2}\right| s_{2}\right),\left(\pi, \theta_{1}\right)\right), \quad \text { where } p / u<\pi<1 ;
$$

d) if $l>-\alpha+k_{2}$ and $p / u<\theta_{1}$ :

$$
\left(\left(s_{2}\left|t_{1}, s_{2}\right| t_{2}\right),\left(a_{1}\left|s_{1}, a_{2}\right| s_{2}\right),\left(\pi, \theta_{1}\right)\right), \quad \text { where } \pi<\min \{p / u, 1\}
$$

\section{Notes}

Earlier versions of this article were presented at the 99th Annual Meeting of the American Political Science Association, Philadelphia, August 28-31, 2003, and the 2nd ECPR Conference, Marburg, September 18-21, 2003. We thank Thomas Bernauer, Gail McElroy, Eddie Hyland, and Mark Smith for very helpful comments. Grant support from the German Research Foundation (Thomas Bräuninger) and the Irish Research Council for the Humanities and Social Sciences (Patrick Bernhagen) is greatly acknowledged.

1 In the analysis that follows, we assume that the firms in our political action scenarios are in structurally equivalent positions (Mizruchi, 1992, pp. 43-7), so that use of the term 'business' as a singular noun is warranted.

2 See Ainsworth, 1993; Austen-Smith, 1993; Lohmann, 1993; Lohmann, 1995; Potters and Van Winden, 1992.

3 Even if the interests of business writ large carried the day in politics, much lobbying would still occur because different sectoral interests would vie for special favors and lobby in competition with other sectoral capitalist interests (see Smith, 2000, pp. 13-7).

4 Interview with an executive of the Irish Business and Employers Confederation (IBEC), Dublin, October 4, 2002.

5 Interview with IBEC executive, October 4, 2002.

6 To be sure, firms have to pay for at least some of the policy-relevant information they want to acquire. The rationale for the assumption of zero information-acquisition costs for firms in our model is rather that many of the relevant expenses will have already been made by the time the firm decides whether or not to lobby against a particular legislation.

7 Interview with the public affairs executive of the German Hotels and Restaurants Association (Deutscher Hotel- und Gaststättenverband, DEHOGA), Berlin, September 2, 2002.

8 As famously stated by the former CEO of General Motors, Charles E. Wilson, during the 1953 Senate hearing that confirmed him as US Secretary of Defense.

9 For the general case that costs for lying occur whenever business sends the wrong signal, we assume the following modification in the payoffs: $\mathrm{P}\left(t_{1}, s_{2}, a_{1}\right)=\left(-\alpha-k_{1},-u\right), \mathrm{P}\left(t_{1}, s_{2}, a_{2}\right)=\left(-k_{2},-\mathrm{p}\right), \mathrm{P}\left(t_{2}, s_{1}, a_{2}\right)=$ $\left(-l-k_{2},-v-p\right)$, where $k_{1}, k_{2}>0$.

10 Note that in the game presented here, with two possible types of a business lobbyist and each actor acting only once, the sets of perfect Bayesian equilibria and sequential equilibria (Kreps and Wilson, 1982) coincide (Fudenberg and Tirole, 1991).

11 There are various other equilibria at knife-edge constellations of parameters. As these are non-generic situations, we do not discuss them here for the ease of presentation.

12 Other selection criteria that are commonly employed in small- $N$ comparative research on interest group politics, such as country-specific characteristics (Grant, Paterson and Whitston, 1988) or those relating to different types of policy (Lowi, 1964) have no bearing on our analysis, in which countries and sectors are not of substantive analytical interest. In comparative studies on interest group politics, countries and policy areas are assumed to summarize a plethora of institutional and structural variables. These variables that are hidden in policy- and country-specific categories in other comparative studies on business and politics, are measured directly in our case studies. For example, $l / k$ will generally be higher in countries where neo-corporatist patterns of interest mediation are key characteristics of public policymaking; $p / u$ will often vary with the policy area concerned; while $\theta_{1}$ can be interpreted as capturing sector-specific vulnerabilities of particular industries as well as the more general economic situation. Our two cases of business lobbying around regulatory policy, furthermore, highlight the limitations of Lowi's (1964) famous typology of policies. Because they impose rules for behavior and are specific and individual in their direct impact, the policies in both our cases 
are explicitly regulatory. Yet, the case of banking regulation constitutes simultaneously an instance of redistributive policy, where losers and winners are clearly distinguishable, while our second case has a clear distributive impact.

13 Interview with a senior manager in the Strategic Development Unit of HSBC, London, April 27, 2004.

14 Interview with HSBC manager, April 27, 2004.

15 Interview with HSBC manager, April 27, 2004.

16 Interview with HSBC manager, April 27, 2004.

17 'Technische Wohnungsbaurichtlinie der Hessischen Landesregierung', Hessischer Landtag, Drucks. $13 / 4403$.

18 Email correspondence with the Technology and Environment officer at the Wiesbaden Chamber of Trade, June 14, 2004.

19 Email correspondence with the Technology and Environment officer at the Wiesbaden Chamber of Trade, June 18, 2004.

20 'Dringlicher Antrag der Fraktionen der SPD und der GRÜNEN betreffend Verwendung umweltfreundlicher Materialien im Wohnungsbau', Hessischer Landtag, Drucks. 13/4582.

21 We would like to thank Frank Baumgartner for this suggestion.

\section{References}

Ackerman, F. and Massey, R. (2003) 'The Economics of Phasing Out PVC,' Unpublished research paper. Somerville MA: Global Development and Environment Institute, Tufts University.

Ainsworth, S. (1993) 'Regulating Lobbyists and Interest Group Influence', Journal of Politics, 55 (1), 41-56.

Austen-Smith, D. (1993) 'Information and Influence: Lobbying for Agendas and Votes', American Journal of Political Science, 37 (3), 799-833.

Bachrach, P. and Baratz, M. S. (1970) Power and Poverty: Theory and Practice. New York: Oxford University Press.

Baumgartner, F. R. and Leech, B. L. (1998) Basic Interests: The Importance of Groups in Politics and in Political Science. Princeton NJ: Princeton University Press.

Berry, J. M. (1989) The Interest Group Society. Second edition. New York: HarperCollins.

Binder, J. J. (1985) 'Measuring the Effects of Regulation with Stock Price Data', Rand Journal of Economics, $16(2), 167-83$.

Birnbaum, P. H. (1984) 'The Choice of Strategic Alternatives under Increasing Regulation in High Technology Companies', Academy of Management Journal, 27 (3), 489-510.

Block, F. (1977) 'The Ruling Class Does Not Rule', Socialist Revolution, 7 (3), 6-28.

Breyer, F. and Ursprung, H. (1998) 'Are the rich too rich to be expropriated? Economic Power and the Feasibility of Constitutional Limits to Redistribution', Public Choice, 94 (1-2), 135-56.

Cerny, P. (1999) 'Globalization and the Erosion of Democracy', European Journal of Political Research, 36 (1), 1-26.

Competition Commission (2002) The Supply of Banking Services by Clearing Banks to Small and Medium-sized Enterprises. London: Stationary Office.

Crenson, M. A. (1971) The Un-politics of Air Pollution: A Study of Non-decision Making in American Cities. Baltimore MD: Johns Hopkins University Press.

Cruickshank, D. (2000) Competition in UK Banking: A Report to the Chancellor of the Exchequer. London: Stationary Office.

Dahl, R. A. (1989) Democracy and Its Critics. New Haven CT: Yale University Press.

Darimont, T. (1995) 'Konversion Chlorchemie', Zeitschrift für Umweltchemie und Ökotoxologie, 7 (5), 280-6.

Department of Trade and Industry (2002) 'Competition in Banking Services for Small and Medium-sized Enterprises.' Press release, London: 14 March.

Downs, A. (1957) An Economic Theory of Democracy. New York: Harper.

Downs, A. (1972) 'Up and Down with Ecology-The Issue-Attention Cycle', The Public Interest, 28 (3), $38-50$. 
EPolitix (2002) 'Forum Brief: SME Bank Accounts.' 14 June. Available from: http://www.ePolitix.com [Accessed 6 May, 2004].

Fudenberg, D. and Tirole, J. (1991) 'Perfect Bayesian Equilibrium and Sequential Equilibrium', Journal of Economic Theory, 53 (2), 236-60.

Getz, K. (1997) 'Research in Corporate Political Action: Integration and Assessment', Business and Society, 36 (1), 32-72.

Girling, J. (1997) Corruption, Capitalism and Democracy. London: Routledge.

Gormley, W. (1983) The Politics of Public Utility Regulation. Pittsburgh PA: University of Pittsburgh Press.

Granato, J. (1996) 'The Effect of Policy-maker Reputation and Credibility on Public Expectations: An Application to Macroeconomic Policy Changes', Journal of Theoretical Politics, 8 (4), 449-70.

Grant, W. (1993) Business and Politics in Britain. Second edition. London: Macmillan.

Grant, W., Paterson, W. E. and Whitston, C. (1988) Government and the Chemical Industry: A Comparative Study of Britain and West Germany. Oxford: Clarendon Press.

HM Treasury (2000) Chancellor of the Exchequer's Budget Speech, 21 March. London: Stationary Office.

HM Treasury (2002) 'Eight main clearing banks agree to competition commission remedies', Press release, 31 October.

HM Treasury (2004) Microeconomic Reform in Britain: Developing Opportunities for All. Basingstoke: Palgrave.

House of Commons/Treasury Committee (2002) Banking, Consumers, and Small Businesses: Fifth Report of Session 2001-02. Volume I, HC 818-1. London: Stationary Office.

Jacob, K. (1999) Ökologische Modernisierung und Strukturwandel in der Chemischen Industrie: Der Fall Chlorchemie. Berlin: Forschungsstelle für Umweltpolitik am Otto-Suhr-Institut für Politikwissenschaft der Freien Universität Berlin.

Kennan, J. and Wilson, R. (1993) 'Bargaining with Private Information', Journal of Economic Literature, 31 (1), 45-104.

Knoke, D., Pappi, F. U., Broadbent, J. and Tsujinaka, Y. (1996) Comparing Policy Networks: Labor Politics in the U.S., Germany, and Japan. New York: Cambridge University Press.

Kreps, D. M. and Wilson, R. (1982) 'Sequential Equilibria', Econometrica, 50 (4), 863-94.

Le Fanu, J. (2004) 'The UK banking market: Consolidation, Competition and the Cruickshank Report.' Die Bank, 3 (March), 150-4.

Lewis-Beck, M. S. and Stegmaier, M. (2000) 'Economic Determinants of Electoral Outcomes', Annual Review of Political Science, 3, 183-219.

Lindblom, C. E. (1977) Politics and Markets: The World's Political-Economic Systems. New York: Basic Books.

Lohmann, S. (1993) 'A Signaling Model of Informative and Manipulative Political Action', American Political Science Review, 87 (2), 319-33.

Lohmann, S. (1995) 'Information, Access, and Contributions: A Signaling Model of Lobbying', Public Choice, 85 (3-4), 267-84.

Lowi, T. J. (1964) 'American Business, Public Policy, Case-Studies, and Political Theory', World Politics, 16 (4), 677-715.

Lukes, S. (1974) Power: A Radical View. London: Macmillan.

McGann, A. J. (2002) 'The Advantages of Ideological Cohesion: A Model of Constituency Representation and Electoral Competition in Multi-party Democracies', Journal of Theoretical Politics, 14 (1), 37-70.

Mills, C. W. (1956) The Power Elite. New York: Oxford University Press.

Mitchell, N. (1997) The Conspicuous Corporation: Business, Public Policy, and Representative Democracy. Ann Arbor MI: University of Michigan Press.

Mizruchi, M. (1992) The Structure of Corporate Political Action: Interfirm Relations and Their Consequences. Cambridge MA: Harvard University Press.

Morton, R. B. (1999) Methods and Models: A Guide to the Empirical Analysis of Formal Models in Political Science. Cambridge: Cambridge University Press.

Morton, R. B. and Cameron, C. (1992) 'Elections and the Theory of Campaign Contributions: A Survey and Critical Analysis', Economics and Politics, 4 (1), 79-108.

Nolte, R. F. and Joas, R. (1995) Handbuch Chlorchemie I - 1992 - Produkte, Unternehmen, Stoffflüsse. Berlin: Umweltbundesamt. 
Peltzman, S. (1973) 'An Evaluation of Consumer Protection Legislation: The 1962 Drug Amendments', Journal of Political Economy, 81 (5), 1049-91.

Potters, J. and Van Winden, F. (1992). 'Lobbying and asymmetric information', Public Choice, 74 (3), 269-92.

Prognos AG (1994) Endbericht: Konversion der Chlorchemie. Wiesbaden: Hessisches Ministerium für Umwelt, Energie und Bundesangelegenheiten.

Przeworski, A. and Wallerstein, M. (1988) 'Structural Dependence of the State on Capital', American Political Science Review, 82 (1), 11-29.

Quinn, D. P. and Shapiro, R. Y. (1991) 'Business Political Power: The Case of Taxation', American Political Science Review, 85 (3), 851-74.

Richardson, J. J. (2000) 'Government, Interest Groups, and Policy Change', Political Studies, 48 (5), $1006-25$.

Richardson, J. J. (1993) 'Pressure Groups and Government' in J. J. Richardson (ed.), Pressure Groups. Oxford: Oxford University Press, pp. 1-15.

Smith, M. A. (2000) American Business and Political Power: Public Opinion, Elections, and Democracy. Chicago IL: University of Chicago Press.

Sunstein, C. (1998) 'Health-Health Trade-offs' in J. Elster (ed.), Deliberative Democracy. Cambridge: Cambridge University Press, pp. 232-59.

Swank, D. (1992) 'Politics and the Structural Dependence of the State in Democratic Capitalist Nations', American Political Science Review, 86 (1), 38-54.

Thatcher, M. (1998) 'The Development of Policy Network Analysis: From Modest Origins to Overarching Frameworks', Journal of Theoretical Politics, 10 (4), 389-416.

Umweltbundesamt (2001) Action Areas and Criteria for a Precautionary, Sustainable Substance Policy using the Example of PVC. Berlin: Erich Schmidt Verlag.

Vogel, D. (1996) Kindred Strangers: The Uneasy Relationship Between Politics and Business in America. Princeton NJ: Princeton University Press.

Wright, J. R. (1996) Interest Groups and Congress: Lobbying, Contributions and Influence. Boston MA: Allyn and Bacon. 